\title{
Mentoring Program in Organic Chemistry Discipline at Agricultural Science Courses from Federal University of São João del-Rei - Campus Sete Lagoas
}

\author{
Costa, L. T.; Melo, C. P. O. F; Rodrigues, D. B.; Souza, A. G.; Garcia, E. M.; \\ Taroco, H. A.; Melo, J. O. F.*
}

Rev. Virtual Quim., 2017, 9 (2), 689-698. Data de publicação na Web: 13 de fevereiro de 2017

http://rvq.sbq.org.br

\begin{abstract}
Programa de Tutoria na Disciplina de Química Orgânica, nos Cursos de Ciências Agrárias, da Universidade Federal de São João del-Rei - Campus Sete Lagoas
\end{abstract}

Resumo: Nas duas últimas décadas (1990-2010), vários países passaram por importantes e significativas mudanças na educação superior. Não diferentemente, no Brasil, devido à implantação de diversos programas de governos, ocorreu uma expansão da educação superior, e possibilitou um maior acesso dos estudantes à graduação. Neste mesmo sentido, aumentou o número de alunos ingressantes, no ensino superior, carentes de conhecimentos básicos que deveriam ter sido adquiridos no Ensino Médio, principalmente nas disciplinas de química, física, matemática e biologia, fatos estes que contribuem para o aumento da evasão e da retenção dos estudantes. Dessa forma, o Programa de Tutoria, na disciplina de Química Orgânica do Curso de Ciências Agrárias-CSL, teve como objetivos: contribuir para a redução da evasão e da retenção dos discentes, além de ampliar os conhecimentos dos discentes na área da Química Orgânica, destacar a importância da tutoria como proposta de intervenção didático-pedagógica nos conteúdos ementários e nas atividades propostas pela disciplina em questão na Universidade Federal de São João del-Rei - campus Sete Lagoas, ampliando os conhecimentos na área da Química e propondo alternativas capazes de otimizar as relações de ensino-aprendizagem dessa disciplina na educação básica. Os resultados obtidos deste programa foram promissores desde a sua implantação. Observou-se uma redução na taxa de evasão dos alunos que cursam a Química Orgânica, com maior índice de aprovação, promovendo um nivelamento dos conhecimentos do ensino básico.

Palavras-chave: Educação Superior; Evasão e Retenção; Ciências Agrárias.

\begin{abstract}
In the last two decades (1990-2010), several countries have undergone important and significant changes in their universities. Not unlikely in Brazil, due to the implementation of several government programs, there was an increase of universities allowing greater application of students. Likewise the number of incoming students lacking the basic knowledge that should have been acquired in high school has increased, especially in the disciplines of chemistry, physics, mathematics and biology, what has influenced the rise number of dropout and retention of students. Thus, the Mentoring Program in the organic chemistry discipline at Agricultural Science courses, aimed helped to reduce dropout and retention of students, besides broadening students' knowledge in organic chemistry. In addition, the program aimed to highlight the importance of mentoring as a proposal of pedagogical/ didactic intervention in content and activities for the discipline of organic chemistry at these courses of the Federal University of São João del- Rei - campus Sete Lagoas; broadening knowledge in chemistry field and proposing alternatives able to optimize better teaching-learning relationship of this discipline in basic education. The program outcomes were promising since its implementation. The organic chemistry students evasion rate decreased, bringing higher rate of approval, promoting a common leveling of basic knowledge.
\end{abstract}

Keywords: Higher education; Evasion and retention; Agricultural Sciences.

* Universidade Federal de São João del-Rei, Departamento de Ciências Exatas e Biológicas, campus Sete Lagoas, Rua Sétimo Moreira Martins, no 188, Itapoã, CEP 35702-031, Sete Lagoas-MG, Brasil.

Monesiomelo@gmail.com DOI: $\underline{10.21577 / 1984-6835.20170041}$

Rev. Virtual Quim. |Vol 9| |No. 2| |689-698| 


\title{
Mentoring Program in Organic Chemistry Discipline at
} Agricultural Science Courses from Federal University of São João del-Rei - Campus Sete Lagoas

\author{
Lidiane T. da Costa, Carla Patricia O. F. Melo, Daiane B. Rodrigues,
} Amauri Geraldo de Souza, Eric M. Garcia, Hosane Aparecida Taroco, Júlio Onésio F. Melo*

Universidade Federal de São João del-Rei, Departamento de Ciências Exatas e Biológicas, campus Sete Lagoas, Rua Sétimo Moreira Martins, no 188, Itapoã, CEP 35702-031, Sete LagoasMG, Brasil.

*onesiomelo@gmail.com

Recebido em 6 de julho de 2016. Aceito para publicação em 10 de fevereiro de 2017

\section{Introduction}

\section{Methods}

2.1. Initial diagnosis

2.2. Selection of beginning tutors

2.3. Tutors activities

\section{Results and discussion}

4. Final considerations

\section{Introduction}

In the last two decades (1990-2010), several countries have undergone important and significant changes in their universities. As an example, in the late 90s, was settled a process of in-depth reform in higher education worldwide by the World Conference on Higher Education held in Paris. ${ }^{1}$ Therefore, respecting their historical characteristics, these countries implemented reforms in their educational systems in order to become more efficient to face the ongoing technological revolution of the production process and its political, social and ethical consequences. $^{2}$

Similarly, these reforms also took place in Brazil, to meet the challenges demanded by the new century, i.e. an urgent, thorough and comprehensive restructuring of higher education that meant, in the new democratic context, a pact between government, educational institutions and society, which resulted in elevated levels of access and permanence, and the standardization of quality. Since 2007, the country had a scenario to promote, consolidate and expand the processes of transformation of the public university, to the increase in vacancies in a decisive and sustainable manner, with academic quality, territorial coverage, social 
inclusion and adequate training to new social paradigms and economic force. ${ }^{3}$

This transformation is associated with economic, social and cultural change, where the university operates evaluating theories, practices, concepts and models, which highlights the importance to evaluate and reflect on teaching practices / learning at the university. ${ }^{4}$

Brazilian universities have expanded, an increase of approximately $7 \%$ per year since the late 90s, in which were recorded 2.125.958 undergraduate students at public and private system in 1998. Comparing this number with 1.377.286 students registered in the year 1980, it is clear that there was an increase of approximately $54 \%$ in this period, while the undergraduate degrees were around $21 \%$, evasion was entirely linked to this imbalance. ${ }^{5}$

The Support Program for the Restructuring and Expansion of Federal Universities (REUNI), created in 2006, arose in this context, with the following objectives: expand the number of vacancies for new students, which allowed greater access especially at night and the reduction of dropout rates and occupation of unfilled vacancies; reviewed the academic structure, which resulted in reorganization of undergraduate and diversified modalities of courses; promoted a pedagogical training to ensure better coordination between basic education, vocational and technology; increased student mobility, both intra- and inter-institutional; increased the social compromise of the institutions, with student assistance programs, university extension and inclusion policies; expanded qualitatively and quantitatively the graduate studies, contributing to the development of administrative undergraduate courses. ${ }^{3-6}$

Besides the REUNI, there was also the strengthening of higher education in Brazil, through the restructuring of Centro Federal de Educação Tecnológica - CEFETs (Federal Centers for Technological Education) and the Instituto Federal de Educação Ciência e Tecnologia - IFETs (Federal Institutes of
Education, Science and Technology); the expansion of funding for students via new financing policies with the implementation of University for All Program - PROUNI (Programa Universidade para Todos) and the Fund for Financing of Higher Education Students - FIES (Fundo de Financiamento ao Estudante do Ensino Superior); stimulating distance learning mode; promoting policies and programs of inclusion and affirmative action and commitment to the formation of basic education teachers. ${ }^{7}$

All these factors have ease the access of students to the university, however, if there is a significant growth in vacancies, attending students from different social conditions, on the other hand, there is an increase in the number of new students lacking basic information from high school, especially in chemistry, physics, mathematics and biology. ${ }^{7}$ The result is increased evasion and/or retention in some subjects, which can sometimes result in abandonment of the course, extended time to conclude the course, increase of public spending and reduced number of undergraduates success.

Thus, this study considers in particular the discipline of chemistry, especially organic chemistry, that is one of the areas in which students have difficulties in learning. Chemistry teaching aims to provide knowledge and understanding of the technological and natural changes that occur in different situations, linking them to the production systems. ${ }^{8}$ For Mortimer, chemistry can be classified as the central science in the design of new materials, offering answers to these varieties of demands, through the knowledge of the properties, formation and transformation of substances. ${ }^{9}$ Santos stated that chemistry is very important in the Agricultural Science courses, promoting greater student interaction in the learning process, awakening understanding of the content taught in class, linking them to laboratory practice activities, and consequently an improvement in the process of professionals training. ${ }^{10}$

In this regard, the theory differs from 
practice, because traditional curricula has revealed, in most cases, that only conceptual aspects of chemistry have been taught, supported by a tendency of not relating school chemistry culture with their scientific backgrounds or with any social or technological context. ${ }^{9}$

Thus, the chemistry teaching has not promoted an integrated training to the students on the scientific development, so that the Mentoring Program in Chemistry for Agricultural Sciences is presented as a tool to bring chemical concepts, since these are fundamental for professionals of Agricultural Sciences. This program is important because chemistry has its presence since the vegetable production systems to post-harvest fruits and vegetables, including the processing of raw materials of plant origin. The concepts of this science are used for control and maintenance of sensory characteristics, nutritional and physicochemical food.

Historically, the evasion of university students is widely debated and analyzed, it commits all Brazilian educational institutions, especially the federal public universities; several factors may occur, although the causes are not well known. Evasion promotes noticeable damage to society, such as: wasted capacity focused on education and training; lower production efficiency in business; loss of national competitiveness; lack of skilled labor, among others. This program can be an effective tool in combating evasion and retention. ${ }^{11}$

According to Brütten, mentoring was originated in Greek mythology and was extended to the contemporary era. ${ }^{12}$ In Greco-Roman mythology, the person named tutor was seen by others as someone anointed with divine protection. ${ }^{13}$

The word Tutor (from latim tutari) means to defend and protect. ${ }^{14}$ Ferreira reported that the tutor was who legally taught and assisted another person. ${ }^{15}$ In education, the student with greater ease in the discipline was appointed tutor and helped other students who faced difficulties. ${ }^{13}$ In this context, the person who helped other students in their tasks, made them gain autonomy, enabling them to build new knowledge, meeting the demands of globalization constantly changing. ${ }^{15}$ In addition, mentoring seeks solutions to conflicts and helps the students to face, effectively, the crisis situations. ${ }^{16}$ Thus, the tutor is anyone who helps others to overcome obstacles. ${ }^{17}$

Mentoring in Spain, Portugal and other European countries took place in different areas of education, where teachers and students acting as tutors / mentors, also called facilitators of learning. ${ }^{18}$ In the United States, tutoring is adopted in several universities to assist students in their difficulties. ${ }^{19}$ In Europe, mentoring has been classified as a teaching / learning strategy that could be used for various purposes, which stands out the aid to students, collectively or individually. ${ }^{13}$

Mentoring has occupied key role in the teaching / learning process, contributing to the academic performance of students with learning difficulties and / or adaptation. Mentoring can be applied as a preventive and / or remedial process. In the first moment, the experienced tutor guides the novice tutor training and development of knowledge, preventing possible difficulties from novice tutor; in the second moment, the experienced tutor helps the novice tutor in problem solving and overcoming difficulties.

Through this research, it was possible to diagnose poor performance of the students of Agricultural Science courses from Federal University of São João del-Rei - campus Sete Lagoas, specifically in the discipline of organic chemistry.

Ways to assess the methodological inefficiency of chemistry teaching in these courses was the preparation of evasion profiles and retention of students in these grades and also the evaluation of the results of the implementation of the tutoring program in the discipline of organic 
chemistry.

The aims of this study were: a) to evaluate the importance of mentoring as didactic and pedagogical intervention in the activities of the discipline of "Organic Chemistry" of Agricultural Science courses from the Federal University of São João del-Rei - campus Sete Lagoas; b) evaluate the contribution to the reduction of evasion and retention of students of this discipline, such as the broadening of knowledge in chemistry and its interaction with other areas of Agricultural Sciences.

\section{Methods}

\subsection{Initial diagnosis}

The methodology adopted for this work is initially based on the bibliographical study of College Education in Brazil in the last two decades (1990-2010), with the implementation of some government programs that have expanded access of students to the university ${ }^{6}$. It was also made a diagnosis of Chemistry Teaching situation for Agricultural Sciences, addressing the difficulties of beginning students, highlighting the mentoring contribution to improving the teaching / learning process. Analysis of historical students from discipline of Organic Chemistry from Federal University of São João del-Rei - campus Sete Lagoas were performed from the first semester of 2013 up until first semester of 2015, to determine the effectiveness of mentoring, reducing dropout and retention of these students.

\subsection{Selection of beginning tutors}

The Mentoring Program began in May 2014. From May to July 2014 tutors were being selected through interview and analysis of the students' coefficient of performance. After selection, there was training, preparation of teaching materials and preparation of activities to be developed with these students (beginning tutors). From August 2014, an experienced tutor trained a novice one. Initially the program was presented to students of organic chemistry discipline, explaining what the Mentoring Program was, who could take part in, how the program would contribute to the qualification and development of the students involved. The selected tutors were introduced to the students as well as their availability. After this explanation, there was the enrollment of students interested in the program.

In the second semester of 2014, 3 tutors were selected and in the first semester of 2015 were selected 4 tutors. In total, both semesters had involved around 40 students who were attending organic chemistry.

\subsection{Tutors activities}

Each tutor supervised about 10 students throughout the semester, but at different schedules. Tutors made 10 hours per week available to the students, of which the assisted could choose 6 hours of compulsory attendance. Activities related to the discipline were developed by checking the difficulty of each student, with the participation of assisted tutors and students in groups of study, whose activities are guided through discussions, interactions and experience exchange. ${ }^{20-23}$ The activities also sought the interaction of students with the research and extension activities, arousing greater interest in the discipline, through the application of chemistry in daily life. ${ }^{20-24}$

At the end of each semester, the tutors have produced a report containing information such as: name of assisted students, frequency, final grade of students in the discipline, personal evaluation of the tutor and students about the mentoring experience.

Based on mentoring and draft final reports, a data to evaluate program result swas tabulated considering the final grades of 
students in organic chemistry.

\section{Results and discussion}

The discipline of organic chemistry is taught in the first semester of Agronomic Engineering, Food Engineering and Forestry
Engineering. The organic chemistry was worked out upon general concepts without the deepening in reaction mechanisms and methods of identification of organic compounds.

Table 1 shows the data from 2013/01 to 2015/01, noting that the Mentoring Program in Chemistry for Agricultural Sciences began in $2014 / 02$.

Table 1. Students enrolled, approved and disapproved, in the discipline of organic chemistry, between 2013/01 and 2015/01

\begin{tabular}{cccccc}
\hline Semester & $\begin{array}{c}\text { Students } \\
\text { enrolled }\end{array}$ & $\begin{array}{c}\text { Approved } \\
(\%)\end{array}$ & Evasion (\%) & $\begin{array}{c}\text { Retention } \\
(\%)\end{array}$ & $\begin{array}{c}\text { Failed } \\
(\%)\end{array}$ \\
\hline $2013 / 01$ & 122 & 23 & 6.5 & 70.5 & 77 \\
$2013 / 02$ & 133 & 28 & 0 & 72 & 72 \\
$2014 / 01$ & 131 & 30 & 15 & 55 & 70 \\
$2014 / 02$ & 151 & 32 & 19 & 49 & 68 \\
$2015 / 01$ & 156 & 36 & 17 & 47 & 64 \\
\hline
\end{tabular}

The results showed $28 \%$ increase in the number of students enrolled during the study period, and the success rate increased by $56.5 \%$. In addition, there was a reduction of $17 \%$ of failure, well as decreased dropout and retention.

Using some preliminary results of the mentoring program, it could be shown graphically, the performance of students enrolled in the course and assess the role of mentoring in these two periods of development (Figure 1).

Despite the failure rate is still above $50 \%$ there was a decrease from $77 \%$ to $64 \%$, with that, there was an increase in $23 \%$ approval rating to $36 \%$.
Dropout and retention profiles among the failed were analyzed, where was found an evasion variation between 2013/01 and $2013 / 02$ due to a $6.5 \%$ evasion reduction to $0 \%$. However, from 2014/01 the evasion rate increased to $15 \%$, maintaining in $2014 / 01$ (19\%) and 2015/01 (17\%). Between the semesters analyzed there was a reduction in the retention of students. In 2013/01 retention was $70.5 \%$ and in 2015/01 this number was $47 \%$, suggesting the success of the mentoring program. There was a reduction in dropout or retention rates in all the semesters analyzed (Figure 2). 


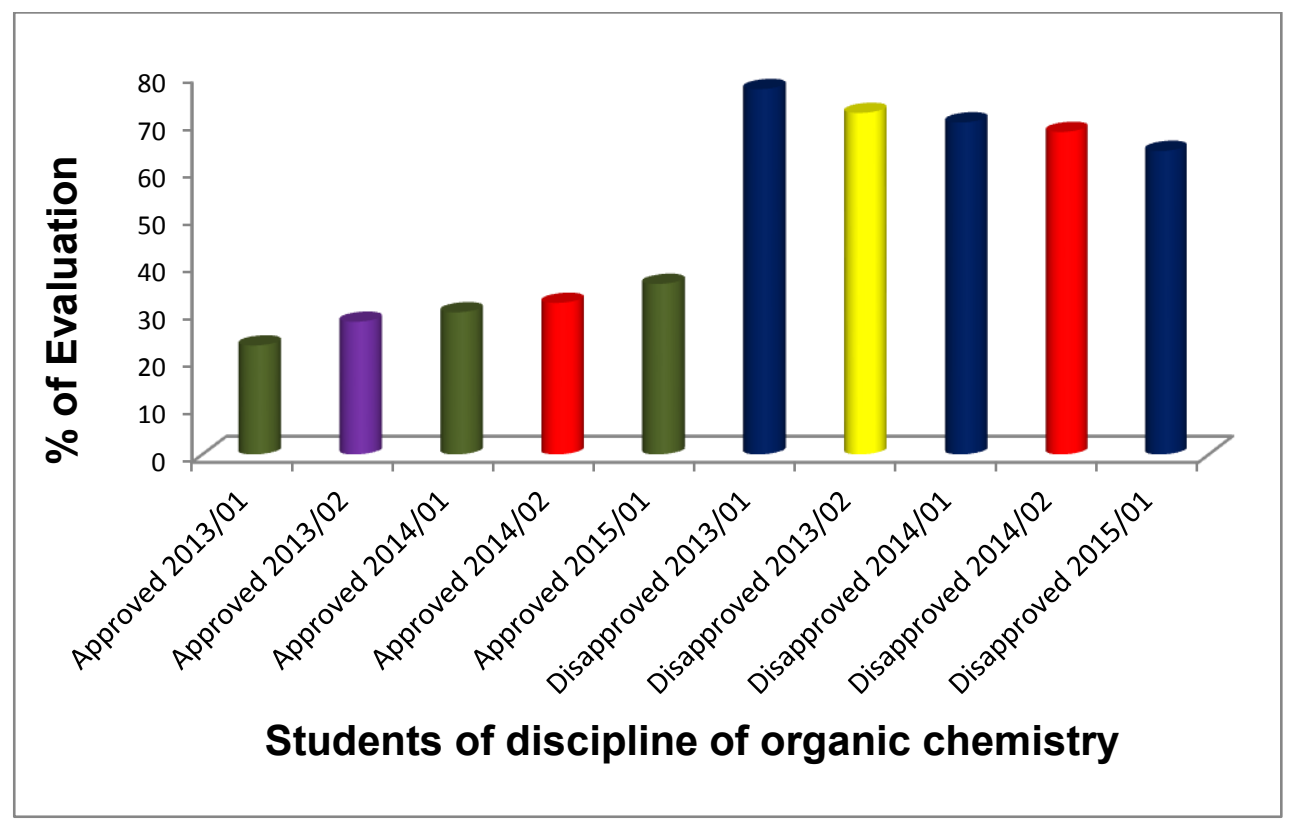

Figure 1. Percentage of approval and disapproval, in the discipline of organic chemistry

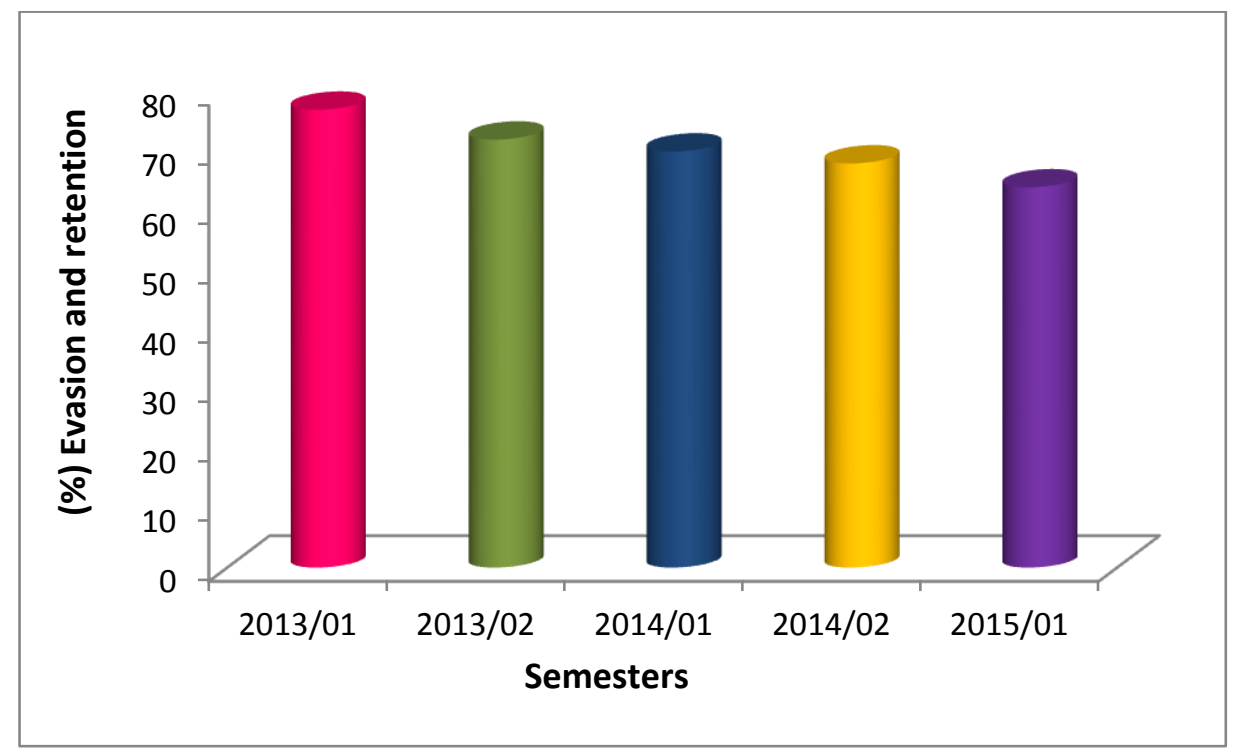

Figure 2. Percentage of evasion and retention in the discipline of organic chemistry

Analyzing only the students involved in the mentoring program, $53 \%$ and $58 \%$ were approved in 2014/02 and 2015/01, respectively (Figure 3 ).

Thus, it was found that despite the reproved are many, the percentage of approved has increased in each period, as well as being higher than the failure rate, showing that tutoring has contributed to the improvement of the teaching / learning process. 


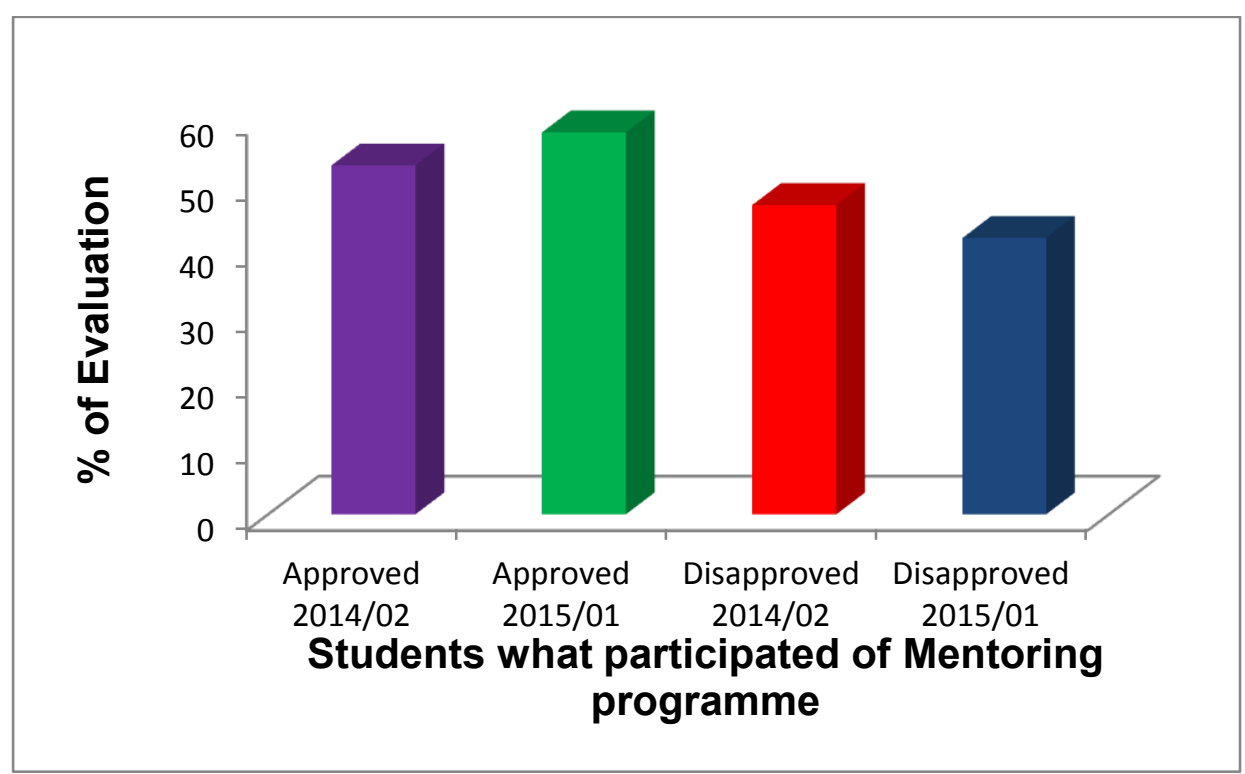

Figure 3. Percentage of approved or disapproved students that participated of the program

Figure 4 shows the performance of students that participated or did not participate in the mentoring Program. About $57 \%$ of students who did not attend the mentoring presented grades between 0.1 to 2. Only $10 \%$ of program participants had similar outcomes. Still, $26 \%$ of students who did not attend the mentoring had score between 6.0 to 8.0 against $50 \%$ of program participants with the same grades (Figure 4).

The results showed that mentoring helps to improve the performance of students, since students without tutoring had lower outcomes than those assisted by the program.

\section{Final considerations}

The permanence of the student in the university assumes preexisting conditions the knowledge acquired over the course of school life and that is not acquired overnight. Thus, the possibilities of joining the university is based in the result of a selection that occurs along the educational path and that is very unequal, per the social background of students. ${ }^{22}$

Therefore, the Mentoring Program in Chemistry for Agricultural Sciences is an efficient tool of didactic and pedagogical intervention, and contributes to the reduction of dropout and retention by promoting the expansion of knowledge. 


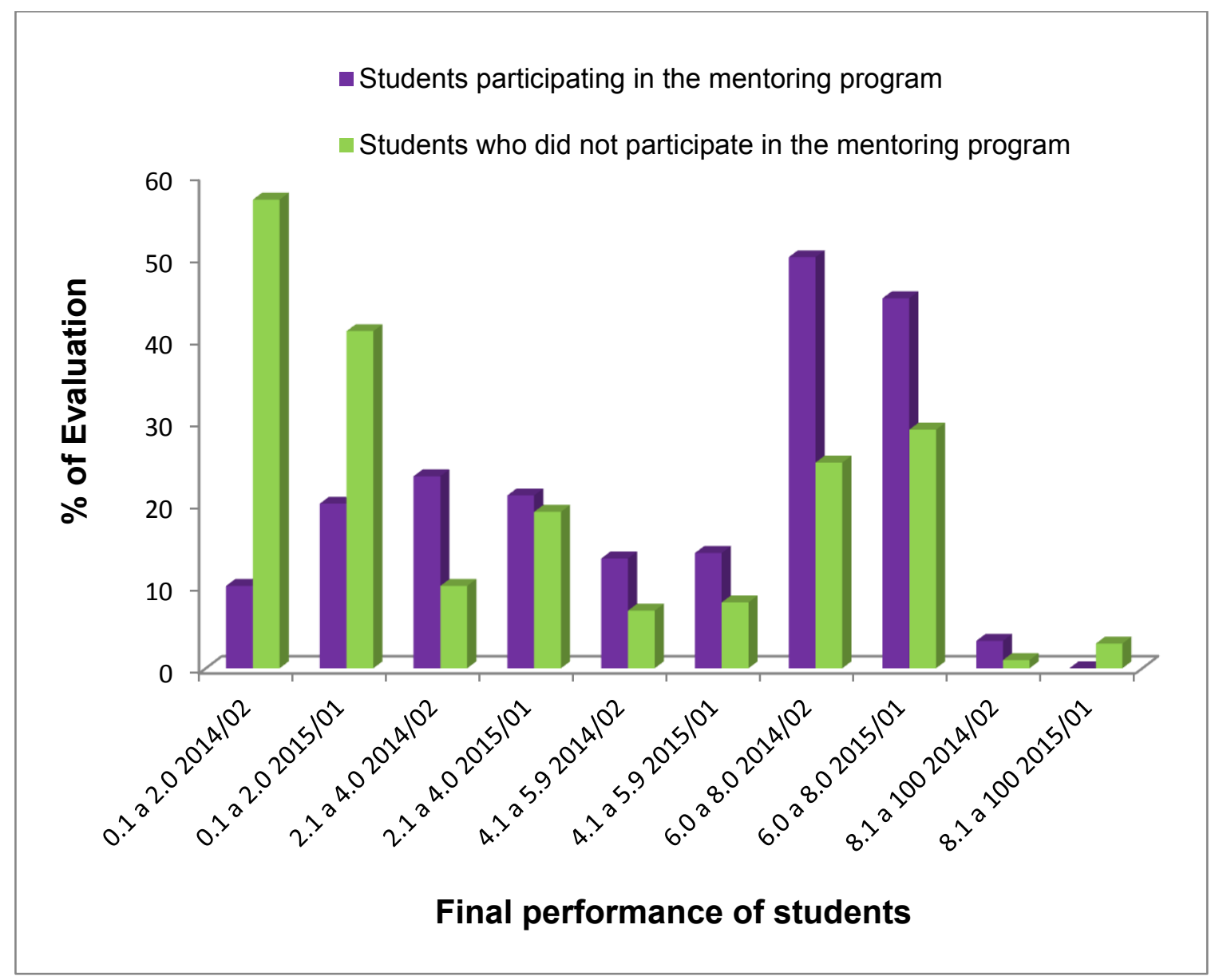

Figure 4. Average grade of the students in the discipline of organic chemistry

\section{References}

${ }^{1}$ Bernheim, C. T.; Chaui, M. Desafios da universidade na sociedade do conhecimento. Série Documentos Ocasionais de Fórum da UNESCO 2008, 44. [Link]

${ }^{2}$ Mello, G. N. D. Cidadania e Competitividade: Desafios Educacionais do Terceiro Milênio. Cadernos de Pesquisa 1995, 92, 89. [Link]

${ }^{3}$ Brasil. Ministério da Educação. Diretrizes Gerais do Programa de Apoio a Planos de Reestruturação e Expansão das Universidades Federais- REUNI, 2007. Disponível em: $<$ portal.mec.gov.br/sesu/arquivos/pdf/diretri zesreuni.pdf>. Acesso em: 10 fevereiro 2017.

${ }^{44}$ Garcia, J. Avaliação e aprendizagem na educação superior. Estudos em Avaliação Educacional 2009, 20, 40. [Link]
${ }^{5}$ Martins, C. B. O ensino superior brasileiro nos anos 90. São Paulo em Perspectiva. 2000, 41, 60. [Link]

${ }^{6}$ Melo, C. P. O. F. Dissertação de Mestrado. Faculdade de Estudos Administrativos de Minas Gerais (FEAD), 2012.

${ }^{7}$ Speller, P.; Robl, F.; Meneghel, S. M. Desafios e perspectivas da educação superior brasileira para a próxima década (20112020). Brasília: UNESCO, CNE, MEC 2012, 164. [Link]

${ }^{8}$ Brasil. Orientações Curriculares para o Ensino Médio: Ciências da Natureza, Matemática e suas Tecnologias, Brasília: MEC/SEMTEC, 2006. Disponível em: <http://portal.mec.gov.br/seb/arquivos/pdf/ book_volume_02_internet.pdf $>$. Acesso em: 10 fevereiro 2017.

${ }^{9}$ Mortimer, E. F.; Machado, A. H.; Romanelli, L. I. A proposta curricular de química do estado de Minas Gerais: fundamentos e 
pressupostos. Química Nova 2000, 23, 273. [CrossRef]

${ }^{10}$ Santos, W. L. P.; Mól, G. S.; Castro, E. N. F.; Silva, G. S.; Matsunaga, R. T.; Farias, S. B.; Santos, S. M. O.; Dib, S. M. F. Química e sociedade: Uma experiência de abordagem temática para o desenvolvimento de atitudes e valores. Química Nova na Escola 2004, 11 [Link]

${ }^{11}$ Silva Filho, R. L. L.; Motejunas, P. R., Hipolito, O.; Lobo, M. B. C. M. A evasão no ensino superior brasileiro. Cadernos de Pesquisa 2007, 37, 641. [Link]

${ }^{12}$ Brutten, E. A tutoria na educação: suas origens e concepções. XVI Colóquio AFIRSE/AIPELF. 2008, 10. [Link]

${ }^{13}$ Frison, L. M. B. Tutoria: Uma Prática de Ensino Autorregulada Utilizada no Ensino Superior. Reflexão e Ação 2013, 21, 66. [Link] ${ }^{14}{ }^{14}$ Ferreira, A. H.; Novo dicionário Aurélio da Língua Portuguesa, 8a. ed, Rio de Janeiro, 2000.

${ }^{15}$ Ferreira, N. S. C.; Roncelii, V.; Gagno, R. R. Tutorias que geram diferentes "Qualidades" na educação básica no Brasil: Concepções e Embates. XVI Colóquio AFIRSE/AIPELF. 2008, 11. [Link]

${ }^{16}$ Casanova, M. P. O Papel da tutoria ao serviço do desenvolvimento curricular. XIX Congresso da AFIRSE. 2012, 16. [Link]

${ }^{17}$ Baudrit, A. A Tutoria em Diferentes Domínios: Situação Atual e Pistas Possíveis a Explorar. In Ana Simão, Ana Caetano e Isabel Freire (org.). Tutoria e mediação em educação. Lisboa: Educa e Autores, 2009. [Link]

${ }^{18}$ Gordea, N. R. Una propuesta de educacion personalizada. Cuadernos de Pedagogia 1988, 26. [Link]

${ }^{19}$ Simão, A. M. V.; Flores, M. A.; Fernandes, S.; Figueira, C. Tutoria no ensino superior: concepções e práticas. Ciências da Educação 2008, 75. [Link]

${ }^{20}$ Ferreira, L. C; Moraes, F. A; Melo, C. P. O. F; Garcia, E. M; Taroco, H. A; Melo, J. O. F. Água como tema central na educação ambiental. Scientific Electronic Archives 2016, 9, 67. [Link]

${ }^{21}$ Moraes, F. A; Ferreira, L. C; Garcia, E. M; Taroco, H. A; Melo, J. O. F. Avaliação sazonal dos parâmetros físico-químicos de fontes alternativas de água na região de Sete Lagoas-MG. Scientific Electronic Archives 2016, 9, 17. [LinK]

${ }^{22}$ Rodrigues, D. B.; Costa, L. T.; Melo, C. P. F.; Souza, A. G.; Garcia, E. M.; Taroco, H. A.; Melo, J. O. F. Analysis of Project about Cerrado fruits developed with students from two public schools. Scientific Electronic Archives 2016, 9, 80. [LinK]

${ }^{23}$ Garcia, Y. M.; Guedes, M. N. S.; Rufini, J. C. M.; Souza, A. G.; Augusti, R.; Melo, J. O. F. Volatile compounds identified in Barbados Cherry 'BRS-366 Jaburú'. Scientific Electronic Archives 2016, 9, 67. [Link]

${ }^{24}$ Bourdieu, P.; Passeron, J. C. Los herederos: lose studiantes y la cultura. Siglo XXI Editores Argentina 2009, 216. [Link] 